\title{
Proximate Analysis of Bycatch Fish and Probiotics Treatments towards the Good Aquaculture Practices
}

\author{
Sudirman Adibrata ${ }^{1 *}$, Rufti Puji Astuti², Novyandra Ilham Bahtera², Rahmad Lingga ${ }^{3}$, \\ Fahmida Manin ${ }^{4}$, Maulana Firdaus 5
}

${ }^{1}$ Department of Aquatic Resources Management, Faculty of Agriculture Fisheries and Biology, Universitas Bangka Belitung 2Department of Agribusiness, Faculty of Agriculture Fisheries and Biology, Universitas Bangka Belitung

${ }^{3}$ Department of Biology, Faculty of Agriculture Fisheries and Biology, Universitas Bangka Belitung

Jl. Raya Balunijuk, Gedung Semangat, Kampus Terpadu UBB Balunijuk, Kecamatan Merawang, Kabupaten

Bangka, 33172, Indonesia

${ }^{4}$ Department of Animal Health Faculty of Animal Husbandry, Universitas Jambi

JI. Jambi - Muara Bulian No.KM. 15, Kabupaten Muaro Jambi, Jambi Indonesia

${ }^{5}$ Department of Agribusiness Management, Graduate School of Agriculture, Tokyo University of Agriculture 1-1-1 Sakuragaoka, Setagaya, Tokyo, 156-8502, Japan

Email: sudirman@ubb.ac.id

\begin{abstract}
Bycatch small pelagic fish during the fishing season can be oversupplied so that its price goes down. The study aims to analyze the proximate of local fish powder from the by-catch and probiotics of Probio_FM in the fish feed in Bangka Belitung. The method was the data compared with the Indonesian National Standard, SNI 01-27151996/Rev: 92 about the raw material of animal feed as fish powder and fish feed with six different treatments. The study found that the bycatch or trash from small pelagic fish could be used as a fish powder or fish feed. The proximate analysis on fish powder and fish feed with probiotics Probio_FM included as the quality of SNI. Crude protein values from $25.75 \%$ until $66.96 \%$ that was above SNI standard I (1.5\%), II (2.5\%), and III (3.0\%) could be followed up into an economical business. Fermented activity from Probio_FM could degrade the protein and other components proximate such as ash content, crude protein, crude fat, crude fiber, calcium, Phosphor, and NaCl. The amino acids from protein were getting simpler and easier being absorbed by fish in culture or livestock farms. Probio_FM was assumed to degrade the protein value and other components proximate due to the utilization of nitrogen and ammonia derived from the process fish protein hydrolyzation of probiotic bacteria. The production of local feed should be implemented to reach feed security and very important to be developed into a community business. Proximate analysis of bycatch could support sustainable good aquaculture practices in the future.
\end{abstract}

Keywords: Bangka Belitung, fish feed, probiotics, small pelagic fish, sustainable, trash

\section{Introduction}

Fisheries have been an essential source of food and a source of livelihood and economic benefits for those involved in fish farming, harvesting, processing, and trading (Ababouch, 2009). Fishermen earn income when the caught fish are sold in the market. Without the provided market, the caught fish will be thrown away (Midrar, 2020). Ward (2007) argues that 10 to 12 million tons of global discards in commercial fisheries contribute more than eight percent of global fish production but it can reach $30 \%$ in some developing countries. Nunoo et al. (2009) state that the increased number of by-catch is due to the overcapitalization and practice of throwing the large number of by-catch away for cost efficiency.

In general, the fish resource in Indonesia is dominated by small pelagic fish with $36 \%$ and big pelagic with $25 \%$ (Suman et al., 2016), while the rest $39 \%$ belong to the other types of fish. The potential small pelagic fish in Indoinesia Fishery Management Area (FMA) 711 is estimated at 330,284 tons. $y^{-1}$ (Kepmen KP No. 50 Tahun 2017). If 10\% of them are in Bangka Belitung Islands Province 33,028.4 tons.y1 can be utilized. There are several ways to utilize trash fish or non-targeted fish to have a value-added; for example, Mo et al. (2018) and Iromo et al. (2020) explain that a large amount of 'trash fish' is directly used as feed or is processed into fish powder for fish feed. The use of local by-catch as feed is suggested as a solution for a safe and sustainable source of animal feed.

Furthermore, by-catch becomes another challenge faced by the fishermen. It combines discarded catch and incidental catch (FAO, 1996). The by-catch should be economically and ecologically utilized (Ido and Kaneta, 2020). The use of fish meal 
for aquafeed is increasing along with the development of aquaculture. The nutrient supply and the input of animal feed should simultaneously grow. The supply of aquafeed industry has improved (New and Wijkström, 2002). Tacon and Metian (2015) argue that fish powder is used in feed formulation with a usage rate of about $15 \%$ on fish or shrimp feed and $5 \%$ on poultry feed. Utilization of by-catch commodities and conversion of fish into fish powder is one of the alternatives to reach the sustainable animal feed. Good quality fish powder has a high protein digestibility and amino acid availability (Anderson et al., 1995). The use of fish powder as feed has a crude protein content from $60 \%$ to $68.5 \%$ and is a rich source of essential fatty acids, minerals, and trace elements (Heuzé et al., 2015).

The ideal feed should contain the balanced nutrition needed by the fish to reach optimal growth (Iskandar and Fitriadi, 2017). Currently, organic fish feed is assisted by probiotic technology. The probiotics of Probio_FM in fish powder processing have more advantages than the conventional ones as they can maintain the quality of fish nutrition and produce fish powder that contains prebiotics, probiotics, and postbiotics (Hendalia et al., 2021). The applied Probio_FM in the feed offers some benefits such as better feed digestibility, good condition of cage environment, and lower feed costs (Astuti et al., 2019; Astuti \& Yulia, 2019), good condition of cage environment (Adibrata et al., 2021), and could also be used in producing silage for cattle (Pranoto, Agustina, \& Astuti, 2020).

The sale and utilization of by-catch provide a strategy to combat hunger, inadequate nutrition, poverty, and a guarantee for improved livelihoods (Nunoo et al., 2009). Local fish meal production is an opportunity that can stimulate the fishermen's economy. In addition, it can produce products that are nutritious, safe, and acceptable for consumers (New and Wijkström, 2002). When feed production remains constant and other sectors compete for the same feed source, the price will go up. If the need for animal feed in the Province of the Bangka Belitung Islands can be met by local fish meal producers, the price can be lower than fish powder that is produced from outside. The primary source of protein in concentrate feed for aquaculture species with limited availability is fish powder from pelagic fish (Olsen and Hasan, 2012). The availability of a local resource necessitates research on alternative proteins in aquaculture management. Thus, the study aims to analyze the proximate of local fish powder from the by-catch and probiotics of Probio_FM in the fish feed.

\section{Materials and Methods}

The study was conducted from October to December 2021. Three stages were applied which were: i) research preparation; ii) production of fish powder and fish feed; and iii) proximate analysis of fish powder and probiotics of Probio_FM in the fish feed. The production of fish powder and fish feed was made in Bangka Regency. The location of the research was shown at Figure 1.

The process design of proximate analysis on fish powder and fish feed was conducted in a home industry scale. First, bycatch was cleaned and sorted. Next, those were ground until smooth. It was then used to produce fish powder and pellets. Those were mixed for all treatments. Those were then dried on the solar dry dome except the sixth treatment whereby the semi-dry fish powder and pellet were put on the pellet molding machine and dried on the mentioned dome. Those were manually controlled to ensure the dough pellets were completely dry. They were packed and labeled based on their treatment so that the samples were easily identified in the laboratory. After a month, the result of the analysis was sent to the researcher to be used as the data in the paper. The observed quality parameters in the study were based on Indonesian National Standard or known as (SNI) 01-2715-1996/Rev.92 on fish powder as fish meal raw materials.

\section{Results and Discussion}

Bangka Belitung Island Province consisted of six regencies and one city. Its sea was included in the IFMA 711 (Figure 1.). People's livelihood in the province were primarily dominated by three sectors which were plantation, mining, and fisheries (BPS, 2021). The number of small pelagic

Table 1. Treatment of Fish Powder

\begin{tabular}{lc}
\hline Materials & Treatments \\
\hline Bycatch (4 kg) & I \\
Bycatch (4 kg), Probio_FM (80 ml) & II \\
Bycatch (4 kg), palm kernel cake (800 gr) & III \\
Bycatch (4 kg), palm kernel cake (800 gr), Probio_FM $(80 \mathrm{ml})$ & $\mathrm{IV}$ \\
Bycatch (4 kg), palm kernel cake (800 gr), Probio_FM $(80 \mathrm{ml})$, coconut pulp (500 gr) & $\mathrm{V}$ \\
Bycatch (5 kg), palm kernel cake (2 kg), Probio_FM $(100 \mathrm{ml})$, coconut pulp (1 kg), bran (2 kg) & VI (Fish feed) \\
\hline
\end{tabular}


Tabel 2. Proximate Analysis Method

\begin{tabular}{lc}
\hline Parameters & Methods \\
\hline Moisture content (\%) max & MP 01 BPMSP (Gravimetri) \\
Ash content (\%) max & MP 05 BPMSP (Gravimetri) \\
Crude protein (\%) min & AOAC 2001.11 2019 \\
Crude fat (\%) max & AOAC 2003.06 2019 \\
Crude fibre (\%) max & MP 06 BPMSP (Gravimetri) \\
Calcium (\%) (Ca) & AOAC 968.08 2019 \\
Phospor (\%) (P) & AOAC 965.17 2019 \\
NaCl (\%) max & MP 09 BPMSP \\
Gross energy (Kkal.Kg-1) & MP 21 BPMSP (Bomb Caloimeter) \\
Carbohydrate (\%) & MP 20 BPMSP (Volumetri) \\
\hline
\end{tabular}

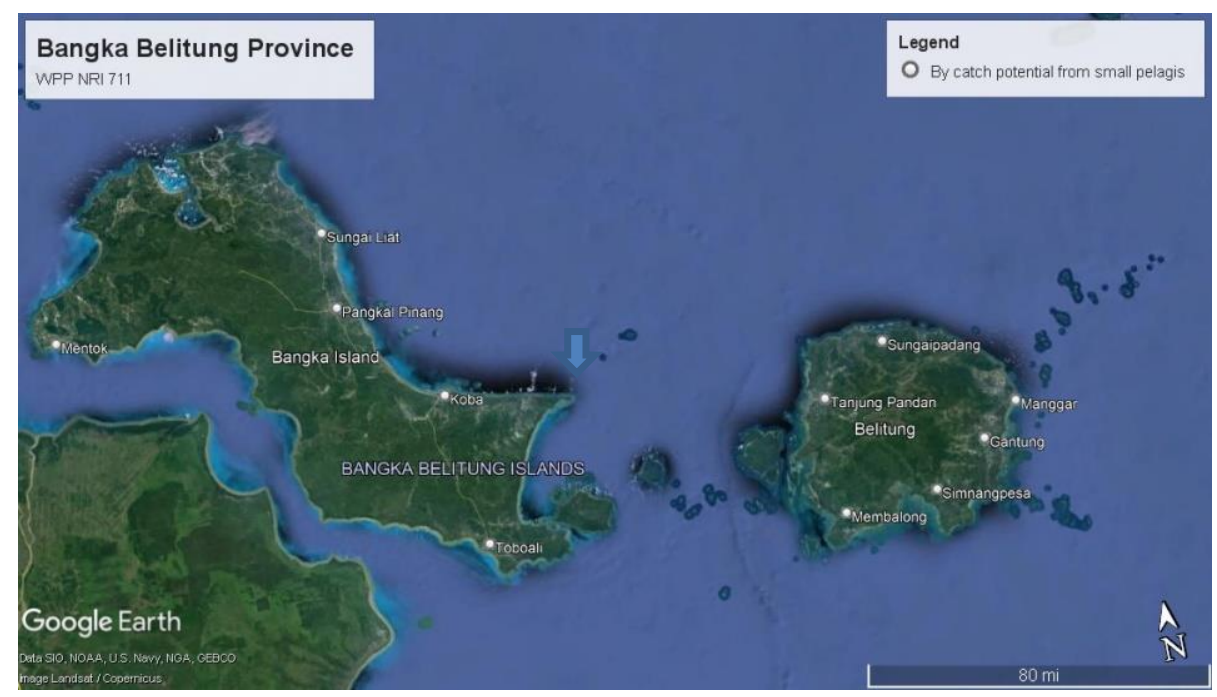

Figure 1. The Location of IFMA 711

fish in the area was potentially estimated at 330,284 tons.y ${ }^{-1}$ (Kepmen KP No. 50 Tahun 2017). The potential of fisheries should be optimized and taken into account the quality aspect and used bycatch. Fish located at low-level pollution such as in Kariba Lake with the proximate analysis had some dry ingredients, protein, and the highest ash content. It correlated with the low level of pollution and high oxygen content in the water (Jim et al., 2017).

According to FAO (1996), bycatch was specifically defined as: a) target catch, which was a catch consisting of one or more species that was a main targeted catch; b) incidental catch, which was not the primary target but was caught and remained after all; c) discarded catch, which was part of the total organic material of animal origin in the catch that was discarded due to economic, rule, or personal consideration; and d) bycatch, which was a combination of discarded catch and incidental catch. Bycatch had become an issue faced by the fishermen who lived far from the market. The small fish and the other marine organisms that were nontarget species were included as the bycatch. The types of bycatch fish collected in this study were sardines (Sardinella aurita), dencis fish (Sardina pilchardus), yellow tufted fish (Selaroides leptolepis), and sand kris fish (Nemipterus nematophorus). All of these bycatch fish could be processed as fish meal. This was different from moonfish, the edible portion of the moonfish was $42.81 \%$ while the rest was $57.19 \%$ as the waste processing (Cahyani et al., 2020). Part of fish as the leftover fish had a bigger portion than the part that was edible.

FAO (1996) stated that the negative effect of the bycatch not only on the community, benthic habitats, biological and ecological impact, but also the economic impact that turned to the social issue. The majority of the bycatch had low economic value and required extra time and energy to sort. Bycatch and leftover fish received attention as they had a relatively tremendous number if they were collected and produced as fish powder. The fish powder could become an alternative source of protein for food fortification (Cahyani et al., 2020). The use of sea materials in aquaculture required an understanding of the efficiency score to achieve the sustainable development goals of the United Nations (Kok et al., 2020). 
In the last decade in Bangka Belitung, aquaculture that was from fresh water and marine had rapidly grown so it needed the feed processing small scale home industry. The industry was vital as many countries needed the input of the fish powder (Olsen and Hasan, 2012). Usually, the raw materials of fish powder were the uneconomic fish, selective by-catch, fish glut, and the leftover fish from the fish processing industry (New and Wijkström, 2002). The fish powder could be used as one of the concentrate ingredients on ruminants to improve the feed efficiency and body weight gain with the optimal level of use at 10\% (Marjuki, 2008). The modified technique of fish powder production was able to produce a fish powder with the third quality of SNI (Harris et al., 2012). The fish powder and fish oil factory could save energy, reduce the cook temperatures around $85^{\circ} \mathrm{C}$ and produce a stable and valuable product (Hilmarsdottir et al., 2020). More than $70 \%$ of the total global aquaculture production relied upon the supply of external feed (Tacon and Metian, 2015).

The process of fish powder production was simple so it could be produced at the household level. It emphasized energy efficiency rather than the quality of materials, protein, or oil. The alternative of fish powder and oil could produce the fish silage (Einarsson et al., 2019). Sometimes, the results of proximate analysis of protein and ash content did not fulfill the nutritional requirements of fish while the crude fat and fiber fulfilled the nutritional requirements of fish (Iskandar and Fitriadi, 2017). The fish powder processing from the fish waste became a business opportunity and had economic value to increase the welfare of the society (Berutu et al., 2018). The economic allocation was a proxy in nutritional value and added value on the by-catch as a result of relative demand (Kok et al., 2020). The price of commercial feed in the market was relatively high considering its quality. However, the dependency on the commercial product should be minimized by emphasizing the production of local feed. The study had to begin from local bycatch for support sustainable aquaculture. The fish powder, fish feed, and proximate data resulted in the study were shown in Figures 2.

\section{Proximate analysis and nutritional value}

In general, fish feed and pellets with probiotic treatment showed that Probio_FM was able to degrade every proximate element so that its value was reduced. However, the level of digestion in the intestines of cultivated biota became faster and healthier because there was the help of beneficial bacteria. The moisturizing content was the percentage of the water content of a particular material that could be identified with a wet or dry basis. The moisturized content was one of the vital characteristics of feed because the water was able to affect the appearance, texture, and taste, especially on the fish feed. Furthermore, it also affected the freshness, durability in which the high level of moisturizing content caused bacteria, mold, and yeast to grow quickly. It then affected the change of the feed materials (Syahfril et al., 2004). The study discovered that treatments I, II, V and VI included SNI II and III. It required even longer drying. The treatments III and IV included SNI I. This indicated that the drying was sufficient and did not need further drying. There were differences between the treatment of fish feed without probiotics and with probiotics. In general, fish feed

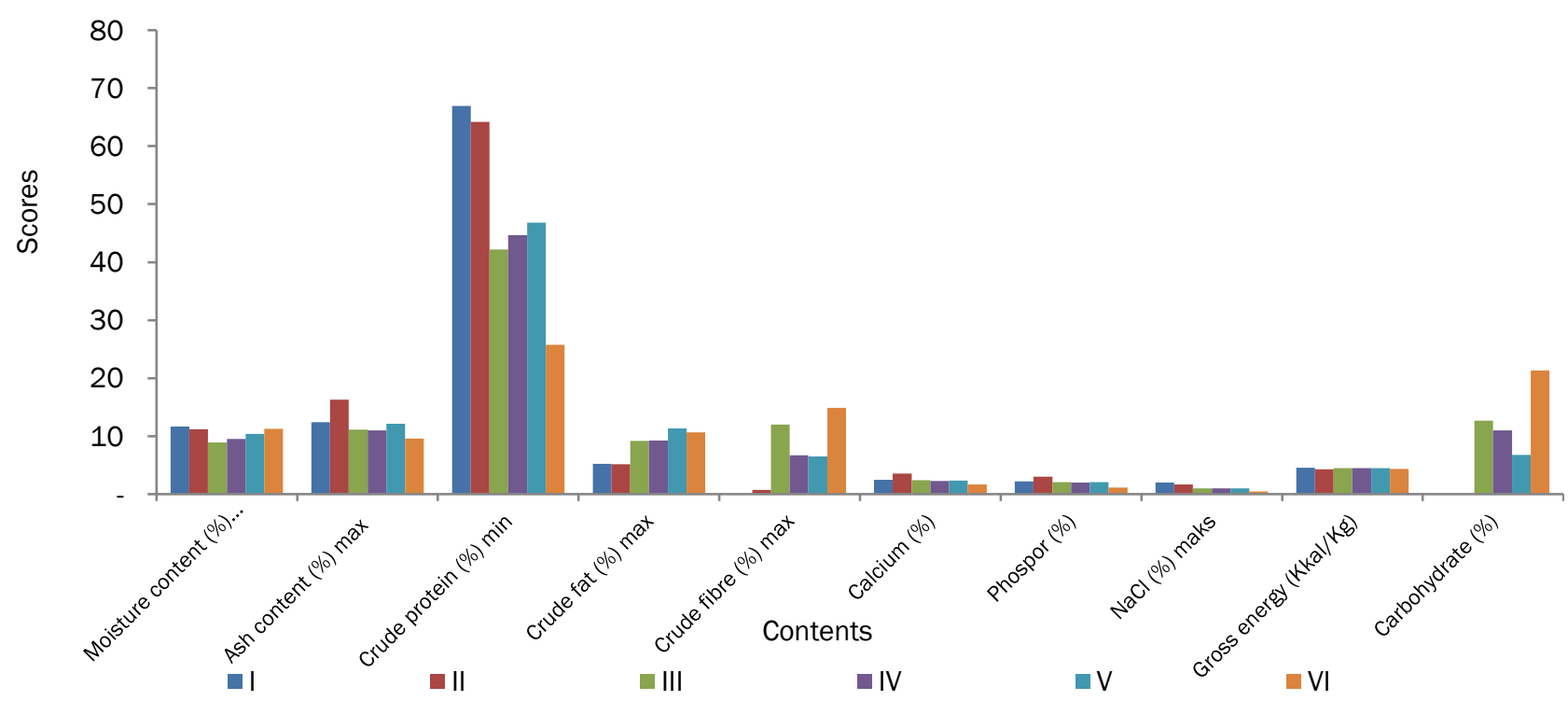

Figure 2. Proximate Composition of Fish Powder at 1st to 6th Treatment 
with probiotics dried in the sun for the same time could dry faster than without probiotics.

The ash content in the fish relied upon the fish habitat related to mineral content in the fish (Suwandi et al., 2014). The food materials that were from the sea were rich in mineral components. It could be viewed by the ash content. The treatments of I to VI indicated that the ash content included SNI I, II, and III. Overall, the treatment of fish feed and pellets with probiotics could reduce the ash content. It could be caused by the reaction of bacteria acting on the media.

The primary function of protein was as essential amino acids that could be used to synthesize non-essential amino acids and protein synthesis in the body. The protein component relied upon amino acids and fish habitat. Protein had a main function for growth and body maintenance, essential components, fluid balance, body neutrality, and antibody formation. The protein in the fish was the highest value after water. It played a vital role in the body's structure and function, such as growth and reproduction. Fish with $15-25 \%$ was included as high protein fish (Dika et al., 2017). In the treatments of I to $\mathrm{VI}$, the protein content was considered as the quality of SNI I, II, and III. While in treatment VI, the value of protein content was below the commercial fish feed (commercial feed over 31\%). The dose of the other prebiotic elements should be reduced and fish powder from bycatch had to be added. The acid element and fermented activity from Probio_FM could degrade the protein. The protein was suggested to break down and change into amino acids to be simpler and easier being absorbed by fish in livestock farming. Figures 2 illustrated that Probio_FM was assumed to degrade the protein value due to the utilization of nitrogen and ammonia derived from the process fish protein hydrolyzation of probiotic bacteria.

The lower value of fat content, the longer the storage time of fish powder was required. The highfat content accelerated the rancidity of fish powder. Crude fat in treatments I to VI already met the criteria of SNI I, II, and III. Only treatments I and II had fat content that met commercial pellet standards. Treatment III to VI, crude fat content was above the commercial pellet standard (commercial feed 4-6\%). The fatty acid in the fish consisted of saturated fatty acids (15-25\%), monounsaturated fatty acids (35$60 \%)$, and polyunsaturated fatty acids (25-40\%) (Berge and Barnathan, 2005). The boiling fish was able to separate the fat quickly from the fish but the protein reduced quickly. The function of the fat was the main source of energy production after carbohydrate and protein for muscle growth. Its function was also as the efficient energy source and as solvent of vitamin that was not absorbed in the water and as essential fatty acids (Dika et al., 2017).

The function of crude fiber was to stimulate the movement of the peristalsis tract as a microbe media in the appendix that produced vitamin $\mathrm{K}$ and B12, as well as to offer feeling full. All treatment resulted in various crude fibers. The crude fiber in treatments I, II, IV, and V already met the criteria of SNI I, II, and III. Only treatments III and VI had crude fiber content that was upper in SNI. In the treatments I and II, crude fiber content was under the commercial pellet standard (commercial feed 3-5\%). Generally, adding Probio_FM reduced the crude fiber. It was assumed that bacteria in Probio_FM played the role in degrading the value of crude fiber.

The content of Calcium (Ca), Phosphor (P), and $\mathrm{NaCl}$ were part of essential minerals that were needed to functionalize the physiology normally. Figure 2 displayed that Probio_FM was assumed to degrade the level of $\mathrm{Ca}, \mathrm{P}$, and $\mathrm{NaCl}$. All treatments showed that the content of $\mathrm{Ca}$ was under the quality of SNI, except the treatment III on Ca entered the criteria of SNI I, II, and III. Calcium could increase hormones in laying poultry or farmed fish. All treatments showed that the content of $P$ was entered the quality of SNI, except the treatment $\mathrm{VI}$ on $\mathrm{P}$ below the criteria of SNI I, II, and III. Phosphor could increase bone stiffness in laying poultry or farmed fish. All treatments showed that the content of $\mathrm{NaCl}$ was entered the quality of SNI, except the treatment I on $\mathrm{NaCl}$ above the criteria of SNI I.

The high cost of gross energy hindered the flexibility of fish farming. Furthermore, the carbohydrate content was considered important. There was an increase in the treatment VI after the addition of coconut pulp and bran. The fish required carbohydrate for energy to keep moving. It was assumed that the Probio FM would degrade the value of gross energy and carbohydrate (Figure 2).

The fish powder was known as the source of protein and energy. It was balanced amongst amino acid, vitamin, essential fatty acid, and trace elements (Bimbo and Crowther, 1992). The potential market in the province was large as tremendous fisheries resources. It should be utilized to improve the quality of life. In terms of nutrition, the fish and shrimp powder had a crucial role in fulfilling the need for protein and minerals (Jahan et al., 2017). The potential mariculture like grouper, brackish water fish like milkfish, shrimp, and freshwater fish like catfish and tilapia urgently required feed from fish powder.

As a sample, the carrying capacity for grouper using the floating net cage system in the water area 
of Pongok Island, Bangka Selatan Regency could be around 16,032,000 grouper fish farming (Adibrata et al., 2013). The potential of mariculture from six regencies and one municipality in Bangka Belitung was very important to be developed into a community business that supported by local fish feed as mariculture feed. Considering the opportunity of fish farming, it required a significant value of nutrition from the tremendous feed source. The production of local feed should be implemented to reach feed security and very important to be developed into a community business. Proximate analysis of bycatch fish and the treatments could support sustainable good aquaculture practices. The fishermen exchange rate figured that they played a vital role in this province's economic growth.

\section{Conclusion}

In summary, bycatch has to be used as fish powder or fish feed. The proximate analysis on fish powder and fish feed with probiotics Probio_FM included as the quality of SNI. Crude protein values from $25.75 \%$ until $66.96 \%$ that is above SNI standard I (1.5\%), II (2.5\%), and III (3.0\%) can be followed up into an economical business. Fermented activity from Probio_FM can degrade the protein and other components proximate such as ash content, crude protein, crude fat, crude fiber, calcium, Phosphor, and $\mathrm{NaCl}$. The protein is suggested to break down and change into amino acids to be simpler and easier being absorbed by fish culture or livestock farms. The production of local feed should be implemented to reach feed security and was crucial to be developed into a community basedbusiness. Proximate analysis of bycatch fish and probiotics treatments can support sustainable good aquaculture practices in the future.

\section{Acknowledgement}

The authors would like to thank the Directorate General of Higher Education, Research, and Technology for funding support and facilities for making this research success through Matching Fund Kedaireka (0493/E/TU.00.01/2021), awarded by the Ministry of Education, Culture, Research, and Technology of the Republic of Indonesia. We also like to thank the Institute of Research and Community Service (Indonesian: Lembaga Penelitian dan Pengabdian kepada Masyarakat or LPPM) and the MBKM students (independent learning program) and Faculty of Agriculture, Fisheries, and Biology Universitas Bangka Belitung for pleasant administration to support us during the research process. Finally, we appreciate Bapak Gunawan from Dinas Sosial Pemberdayaan Masyarakat Desa, Ibu Gusva Yetti from Dinas Pertanian and Metsuwa Diforma as a director of CV Dua Agri Mandiri for their time and energy to support the research.

\section{References}

[BPS] Badan Pusat Statistik. 2021. Provinsi Kepulauan Bangka Belitung Dalam Angka. Badan Pusat Statistik Provinsi Kepulauan Bangka Belitung. Pangkalpinang. 593 pp.

[FAO] Food and Agricultural Organization, fisheries technical paper 339. 1996. A global assessment of fisheries by catch and discards. FAO. Rome. 233 pp.

[Kepmen KP] Keputusan Menteri Kelautan dan Perikanan No. 50 tahun 2017. Estimasi potensi, jumlah tangkapan yang diperbolehkan, dan tingkat pemanfaatan sumberdaya ikan di Wilayah Pengelolaan Perikanan Negara Republik Indonesia. Jakarta.

Ababouch, L. 2009. Fish utilization and trade. In Second International Congress on Seafood Technology on Sustainable, Innovative and Healthy Seafood (p. 9).

Adibrata, S., Bahtera, N. I., Astuti, R. P., \& Arkan, F. (2021). The perception level on the impact of integrated livestock-fish production systems towards the environmental pollution. IOP Conference Series: Earth and Environmental Science, 926(1): 012008. https://doi.org/ 10.1088/1755-1315/926/1/012008

Adibrata, S., Kamal, M.M. \& Yulianda, F. 2013. Daya dukung lingkungan untuk budidaya kerapu (Famili Serranidae) di perairan Pulau Pongok Kabupaten Bangka Selatan. J. Pesisir dan Pulau-pulau Kecil 2(1): 43-58.

Anderson, J.S., Lall, S.P., Anderson, D.M. \& McNiven, M.A. 1995. Availability of amino acids from various fish meals fed to Atlantic salmon (Salmo solar). Aquaculture, 138(1-4): 291-301. https://doi.org/10.1016/00448486(95)0113 $1-5$

Astuti, R.P., Manin, F., Adriani, A., Bahtera, N.I. \& Adawiyah, C.R. 2019. The Agricultural Extension Services to Stock Farmers through Utilizing The Probio_Fm in Improving The Productivity of Beef Cattle in Central Bangka, Indonesia. In 1st Workshop on Multimedia Education, Learning, Assessment and its Implementation in Game and Gamification (pp. 3-8). Medan: EAl. https://doi.org/10.4108/eai.26-1-2019.228 3322 
Astuti, R.P. \& Yulia. 2019. Pemberdayaan Kelompok Tani dalam Pembuatan Probio_Fm sebagai Bahan Fermentasi Pakan Ternak di Bangka Tengah. Agrokreatif J. Ilmiah Pengabdian Masyarakat, 5(2): 141-149. https://doi.org/ 10.29244/agrokreatif.5.2.141-149

Berge, J.P. \& Barnathan, G. 2005. Fatty acids fromlipids ofmarine organisms: molecular biodiversity, roles as biomarkers, biologically active compounds, and economical aspects. Adv Biochem Engin/Biotechnol 96: 49-125. https://doi.org/10.1007/b135782

Berutu, N., Hidayat, A., Syahputra, H. \& Harefa, M.S. 2018. Pengolahan tepung ikan dari limbah ikan di Desa Regemuk Kecamatan Pantai Labu Kabupaten Deli Serdang. J.Pengabdian Kepada Masyarakat 24(1): 510-515. https://doi.org/ 10.24114/jpkm.v24i1.8941

Bimbo, A.P. \& Crowther, J.B. 1992. Fish Meal and Oil: Current Uses. J. Am. Oil Chemists' Soc., 69(3): 221-227.https://doi.org/10.1007/BF026358 90

Cahyani, R.T., Bija, S. \& Sugi, L.T.N. 2020. Karakteristik ikan bulan-bulan (Megalops cyprinoides) dan potensinya sebagai tepung ikan. Teknologi Pangan, 11(2): 182-191. https://doi.org/10.35891/tp.v11i2.2030

Dika, F.A., Brahmana, E.M. \& Purnama, A.A. 2017. Uji Kandungan Protein Dan Lemak Pada Ikan Bada (Pisces: Rasbora spp.) Di Sungai Kumu Kecamatan Rambah Hilir Kabupaten Rokan Hulu. J. Mahasiswa Prodi Biologi UPP, 3(1): 1-5.

Einarsson, M.I., Jokumsen, A., Bæk, A.M., Jacobsen, C., Pedersen, S.A., Samuelsen, T.A., Pálsson, J., Eliasen, O. \& Flesland, O. 2019. Nordic Centre of Excellence Network in Fishmeal and Fish oil. Report Matís 6-19. Project no. 62477. Funding AG-fund, EU fishmeal.

Harris, H., Efreza, D. \& Nafsiyah, I. 2012. Potensi pengembangan industri tepung ikan dari limbah pengolahan makanan tradisional khas Palembang berbasis ikan. J Pembangunan Manusia 6(3): 1-15.

Hendalia, E., Manin, F. \& Adriani. 2021. Evaluasi Nutrisi Tepung Ikan Rucah yang Diolah MenggunakanProbiotik dan Precursor-Prebiotik dalam ransum Ayam Broiler. J. Sain Peternakan Indonesia, 16(2): 114-122. https://doi.org/10. 31186/jspi.id.16.2.114-122
Heuzé, V., Tran, G., Noziere, P., Lessire, M. \& Lebas, F. 2015. Linseed meal. Feedipedia, a programme by INRA, CIRAD, AFZ and FAO. Accessed date : 16 January 2022

Hilmarsdottir, G. S., Ogmundarson, O., Arason, S. \& Gudjónsdóttir, M. 2020. The Efects of Varying Heat Treatments on Lipid Composition during Pelagic Fishmeal Production. Processes, 8(1142): 1-15. https://doi.org/10.3390/pr80 91142

Ido, A. \& Kaneta, M. 2020. Fish Oil and Fish Meal Production from Urban Fisheries Biomass in Japan. Sustainability, 12: 1-13. https://doi.org/ $10.3390 /$ su12083345

Iromo, H., Rachmawani, D., Jabarsyah, A., Zainuddin, Z. (2020). Utilization of Trash Fish for Cultivation of Crablet Mud Crab (Scylla serrata). ILMU KELAUTAN: Indonesian Journal of Marine Sciences, 25 (3): 110-114 (doi:10.14710/ ik.ijms.25.3.110-114)

Iskandar, R. \& Fitriadi, S. 2017. Analisa proksimat pakan hasil olahan pembudidaya ikan di Kabupaten Banjar Kalimantan Selatan. Ziraa'ah 42(1): 65-68.

Jahan, S.N., Bayezid, M.A., Islam, B., Siddique, M.A.B., Karmokar, P.K. \& Flowra, F.A. 2017. Biochemical quality assessment of fish powder. Am. J. Food Nutrition, 5(3): 110-114. https://doi.org/10.12691/ajfn-5-3-6

Jim, F., Garamumhango, P. \& Musara, C. 2017. Comparative Analysis of Nutritional Value of Oreochromis niloticus (Linnaeus), Nile Tilapia, Meat from Three Different Ecosystems. J. Food Quality, 1-8. https://doi.org/10.1155/2017/ 6714347

Kok, B., Malcorps, W., Tlusty, M. F., Eltholth, M. M., Auchterlonie, N. A., Little, D. C., Harmsen, R., Newton, R. W., \& Davies, S. J. 2020. Fish as feed: Using economic allocation to quantify the Fish In: Fish Out ratio of major fed aquaculture species. Aquaculture, 528: 1-10. https://doi. org/10.1016/j.aquaculture.2020. 735474

Marjuki. 2008. Penggunaan tepung ikan dalam pakan konsentrat dan pengaruhnya terhadap pertambahan bobot badan kambing betina. Ternaktropika, 9(2): 1-13.

Midrar, A. 2020. Optimizing the Utilization of Potential Fisheries Resources in Coastal 
ILMU KELAUTAN: Indonesian Journal of Marine Sciences March 2022 Vol 27(1):37-44

Communities. J. La Lifesci 1(1): 24-27. https://doi.org/10.37899/journallalifesci.v1i1.44

Mo, W.Y., Man, Y.B. \& Wong, M.H. 2018. Use of food waste, fish waste and food processing waste for China's aquaculture industry: Needs and challenge. Sci. Total Environ., 613: 635-643. https://doi.org/10.1016/j.scitotenv.2017.08. 321

New, M.B. \& Wijkström, U.N. 2002. Use of fishmeal and fish oil in aquafeeds: further thoughts on the fishmeal trap. FAO. FAO Fisheries Circular No. 975. Rome. 61 hal.

Nunoo, F.K.E., Boateng, J.O., Ahulu, A.M., Agyekum, K.A. \& Sumaila, U.R. 2009. When trash fish is treasure: the case of Ghana in West Africa. Fish. Res., 96(2-3): 167-172. https://doi.org/10.10 16/j.fishres.2008.10.010

Olsen, R.L. \& Hasan, M.R. 2012. A limited supply of fishmeal: Impact on future increases in global aquaculture production. Trends in Food Sci. Technol., 27: 120-128.

Pranoto, Y.S., Agustina, F. \& Astuti, R.P. 2020. Pemanfaatan Teknologi Probio_Fm dalam Penerapan Sistem Integrasi Sapi Kelapa Sawit di Bangka Tengah. Agrokreatif: J. IImiah Pengabdian Kepada Masyarakat, 6(3): 213221. https://doi.org/10.29244/agrokreatif.6. 3.213-221
Suman, A., Irianto, H.E., Satria, F. \& Amri, K. 2016. Potensi dan tingkat pemanfaatan sumberdaya ikan di Wilayah Pengelolaan Perikanan Negara Republik Indonesia (WPP NRI) tahun 2015 serta opsi pengelolaannya. J. Kebijak. Perikan. Ind. 8(2): 97-110.

Suwandi, R., Nurjanah. \& Margaretha, M. 2014. Proporsi bagian tubuh dan kadar proksimat ikan gabus. J. Pengolahan Hasil Perikanan Indonesia. 17(1): 22-28. https://doi.org/10. 17844/jphpi.v17i1.8134

Syahfril, I., Supriyantini, E. \& Ambariyanto. 2004. Studi Kandungan Proksimat Kerang Jago (Anadara inaequivalvis) di Perairan Semarang. IImu Kelautan: Indonesia Journal of Marine Sciences, 9 (4): 190-195.

Tacon, A.G.J. \& Metian, M. 2015. Feed Matters: Satisfying the Feed Demand of Aquaculture. Rev. Fish. Sci. Aquac., 23: 1-10. https://doi. org/10.1080/23308249.2014.987209

Ward, A. R. 2007. Post harvest loss assessment in PP3 zones of Cameron, Chad, Gambia and Senegal: key learning. FAO/DFID Sustainable Fisheries Livelihoods Programme - Post harvest Fisheries Livelihoods Pilot Project. Cotonou, Benin, SFLP-FAO. 60 pp. 